\title{
Organology of Dreams and Archi-Cinema
}

\author{
Bernard Stiegler
}

A B STR ACT Stiegler argued in Cinematic Time and the Question of Malaise (the third volume of Technics and Time) that we must refer to archi-cinema just as Derrida spoke of archi-writing. In this article he proposes that in principle the dream is the primordial form of this archi-cinema. The archi-cinema of consciousness, of which dreams would be the matrix as archi-cinema of the unconscious, is the projection resulting from the play between what Husserl called, on the one hand, primary and secondary retentions, and what Stiegler, on the other hand, calls tertiary retentions, which are the hypomnesic traces (that is, the mnemo-technical traces) of conscious and unconscious life. There is archi-cinema to the extent that for any noetic act - for example, in an act of perception - consciousness projects its object. This projection is a montage, of which tertiary (hypomnesic) retentions form the fabric, as well as constituting both the supports and the cutting room. This indicates that archi-cinema has a history, a history conditioned by the history of tertiary retentions. It also means that there is an organology of dreams.

KEYWORDS Archi-cinema, Derrida, tertiary retention, hypomnesic traces, dream

Voilà presque cinquante ans que, dans le noir, lé peuple des salles obscures brûle de l'imaginaire pour réchauffer du réel. Maintenant celui-ci se venge et veut de vraies larmes et du vrai sang

Mais de Vienne à Madrid, de Siodmak à Capra, de Paris à I os Angeles et Moscou, de Renoir à Malraux et Dovjenko, les grands réalisateurs de fiction ont été incapables de contrôler la vengeance qu'ils avaient vingt fois mise en scène.

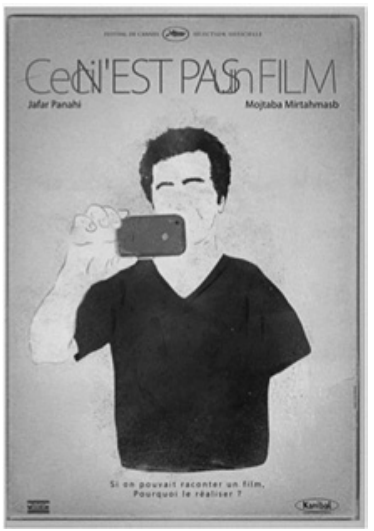


I argued in Le temps du cinéma, that is, in the third volume of Technics and Time, that we must refer to archi-cinema just as Derrida spoke of archi-writing. I propose today and in principle that the dream is the primordial form of this archi-cinema - and this is why an organisation of dreams is possible. The archi-cinema of consciousness, of which dreams would be the matrix as archi-cinema of the unconscious, is the projection resulting from the play between what Husserl called, on the one hand, primary and secondary retentions, and what I, on the other hand, call tertiary retentions, which are the hypomnesic traces (that is, the mnemotechnical traces) of conscious and unconscious life. There is archi-cinema to the extent that for any noetic act - for example, in an act of perception - consciousness projects its object. This projection is a montage, of which tertiary (hypomnesic) retentions form the fabric, as well as constituting both the supports and the cutting room. This indicates that archi-cinema has a history, a history conditioned by the history of tertiary retentions. It also means that there is an organology of dreams.

A temporal process occurs through the continuous aggregation of primary retentions: time only passes because the present instant retains within it the preceding instant. In the temporal flux or flow of sensible intuition that is perception, consciousness apprehends the perceived by primarily retaining data that it selects on the basis of those secondary retentions (memories of past experience) that constitute the selection criteria in the flow of primary retentions.

Each consciousness is constituted from specific secondary retentions that weave its experience, that is, its memory. It is for this reason that, confronted with the same object, two different consciousnesses experience two different phenomena: the phenomena are projected by the consciousness. This projection also projects protentions, that is, expectations. The arrangement or assemblage of primary and secondary retentions with protentions constitutes an attentional form: attention is what is woven between retentions and protentions.

Just as it is necessary to distinguish between primary retentions and secondary retentions, so too is it necessary to distinguish primary protentions and secondary protentions. Secondary protentions are contained and concealed in secondary retentions, whereas primary protentions are inscribed with primary retentions - so that they activate, in passing into secondary retentions, associative modalities such as those described by Hume (contiguity, resemblance and causality). 
On the basis of an object, consciousness projects a phenomenon that is an arrangement of primary and secondary retentions and protentions, and the same object will, each time, result in different phenomena for different consciousnesses. Furthermore, if one and the same consciousness repeats an experience of the same object at different times, a different phenomenon will be generated each time. This is so for two reasons:

- the first reason is that the consciousness that encounters an object for the second time is no longer the same as the one that encountered it the first time, for the precise reason that the primary retentions and protentions from the first encounter have since become secondary retentions and protentions, which in the second encounter supply new selection criteria for the primary retentions and protentions of the object - of which the phenomenon is different each time;

- the second reason is that the way in which secondary retentions select primary retentions in the temporal flow is the result of the play between two types of secondary protentions contained and hidden in secondary retentions: some of these secondary protentions, which become practically automatic, constitute stereotypes, that is, habits and volitions, while others constitute traumatypes - which are either repressed, or expressed by default in symptoms and fantasies.

From all this it follows that the same object can:

- either activate traumatypes, which means that the phenomenon that it engenders constantly differentiates itself by intensifying itself, and that consciousness projects itself into the object by individuating itself with it;

- or activate stereotypes, which means that the phenomenon of the object is its impoverishment, and that the attention that consciousness has for this object fades away, disindividuating itself by reinforcing these stereotypes.

The constitution of phenomena, woven from stereotypes and traumatypes that a consciousness thus projects onto an object, is the result of attentional forms that are conditioned in specific ways by tertiary retentions that support secondary retentions. These are in fact woven from collective secondary retentions, which are elaborated and transmitted 
from generation to generation, and which form symbolic milieus metastabilising what Simondon called the transindividual, that is, signification.

For example, the memory of secondary retentions is to a significant extent composed of verbal traces that are themselves conditioned by a language that is inherited by the consciousness - or what I call the psychic individual. To put this in the language of Gilbert Simondon, psychic individuation is always inscribed in processes of collective individuation through which it shares collective secondary retentions, which form meanings, that is, the transindividual.

The transindividual is formed in and by circuits of transindividuation at the core of which there forms a compromise between diachronic traumatypes and synchronic stereotypes - stereotypes forming signifcations as common usages, and traumatypes forming sense as object investments that disrupt common usage.

The transindividual can only metastabilise itself because it is supported by tertiary retentions, that is, technical supports of various kinds. Technical objects in general are themselves such supports, and they form what Leroi-Gourhan described as the third memory of technical and noetic life, appearing two million years ago: beyond the common genetic memory of the human species and the epigenetic memory belonging to each individual human, there is an epiphylogenetic memory that constitutes the various forms of inherited and transmitted human knowledge, and through which the transindividual is metastabilised.

It should be noted here that technical and hypomnesic objects play a major role in the dream as analysed by Freud in his Interpretation of Dreams, and that desire is constituted in Freud around the fetish, that is, the artefact - which means that, like the artefact, the libido is detachable and can move from organ to organ (both artificial and corporeal).

Rupestral mnemo-technical supports [that is, cave paintings] appear around thirty thousand years ago, and these project mental contents outwards,

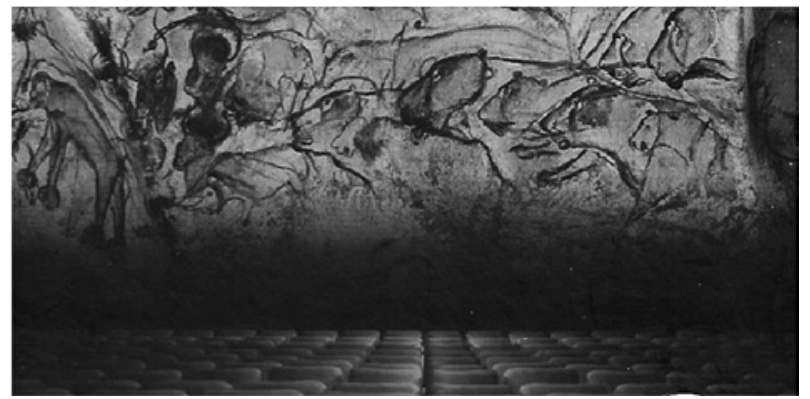


constitute hypomnesic tertiary retentions, and initiate a process of grammatisation.

Grammatisation, as I use the term, refers to the process by which the mental temporal flows experienced by the psychic individual are recorded, reproduced, discretised and spatialised. When we see the Chauvet cave paintings, we are aware that what we see are the traces of what was seen and experienced by those who painted them. We are aware that we are accessing a new empathic possibility that did not exist prior to the Upper Paleolithic era, even though it is also true that those tertiary retentions that every object constitutes already allow us to access the artificial memory of a form of life itself artificial, and of which we are the inheritors.

The appearance of hypomnesic tertiary retentions results in new regimes of individuation through the play of the primary and secondary retentions and protentions in which attention consists: it leads to new attentional forms. On the basis of the example of the melody that Husserl used to construct his concept of primary retention, I have tried to show that tertiary retention conditions the play of primary retention and secondary retention, and therefore the play of primary protention and secondary protention: I have highlighted the fact that the analogue tertiary retention in which the phonogram consists, insofar as it enables the identical repetition of the same musical temporal object, results in a new primary and secondary retentional and protentional experience of a piece of music. In fact, each repetition manifestly engenders a difference from out of one and the same object, and this experience of the production of difference through analogue repetition constitutes a new experience of music itself - a new form of experience that is a new form of attention, dating very precisely from 1877 , and there is no doubt that this contributed to the musical experience inaugurated by Schönberg as well as to what is called 'acousmatic' music.

This new attentional form in fact considerably dramatises and intensifies the difference between two forms of repetition (those referred to by Deleuze in Difference and Repetition): in the first case, stereotypical protention repeats itself and exhausts the object because the phenomenon it generates is a little weaker each time until in the end it disappears; in the other form of repetition, however, the object generates new phenomena every time, intensifying and deepening its difference.

Similarly, cinema is a new experience of life that begins in 1895 . These dates, 1877 and 1895, constitute two immense turns in the organological history of the power(s) to dream. 
Between stereotypes and traumatypes there is play involved in the putting to work of secondary retentions and protentions that select primary retentions and protentions, and this play is over-determined by tertiary retentions as organological conditions of repetition. As such, a tertiary retention always constitutes a kind of transitional object, in the Winnicottian sense according to which the first retentions and protentions that form the psychic apparatus of the baby are articulated with the retentions and protentions of its mother through the transitional object that opens the transitional space of play.

I argued in What Makes Life Worth Living that the transitional object is a pharmakon: it is the primordial pharmakon - just as for Plato writing was a pharmakon, and as all tertiary retention is a pharmakon, that is, a poison and a remedy. Winnicott showed that the transitional object, which is the condition of the formation of the infantile psychic apparatus, can also become a pathogenic factor if the mother fails to locate therapeutic value of the object and thereby allows it to become an object of pure addiction.

Tertiary retention, which is itself irreducibly pharmacological, is what Socrates grasped for the first time in the Phaedrus through writing this being a literal (that is, lettered) form of tertiary retention. Socrates showed that literal tertiary retention can bring about short-circuits in the play of psychic secondary retentions and can result - via collective secondary retentions that form topoi, that is, commonplaces - in stereotypical ways of selecting primary retentions, that is, it can disindividuate collective individuals and psychic individuals, and transform them into crowds and masses.

It is because analogue tertiary retention is also such a pharmakon that Benjamin could be concerned about the importance of radio to Italian fascism, that this radio could support the language of the Nazi Third Reich, as Victor Klemperer described, and that Adorno and Horkheimer were able to suspect cinema of short-circuiting the transcendental imagination.

And yet, I argue that tertiary retention in general, and in particular literal tertiary retention, analogue tertiary retention and digital tertiary retention all also constitute positive pharmacological possibilities, that is, they generate new attentional forms, forming therapeutic practices from those pharmaka that are tertiary retentions, and of which the cinematic art is one case.

From these general considerations, I would like now to return to the question of archi-cinema, of which the dream is the primordial form, in 
order to pose the question of an organology of the dream in general and, on the basis of this question, I would like to investigate the future of cinema in the epoch of digital tertiary retention.

I argued in the third volume of Technics and Time that Adorno and Horkheimer, by placing themselves within the Kantian perspective on the transcendental imagination, closed off all possibility of thinking a positive pharmacology of the cinema - that is, of the cinematic art itself. For in fact, the cinematic pharmakon as art is what makes it possible to struggle against the cinema as toxic pharmakon, that is, as what enables the short-circuiting of the play of the traumatypical secondary retentions and protentions of psychic individuals by reinforcing their stereotypical secondary retentions and protentions.

Adorno and Horkheimer did not take into account that the three syntheses of the imagination described by Kant presuppose a fourth synthesis, which I call the technological synthesis of the imagination, and which is that of tertiary retention. The first three syntheses (apprehension, reproduction and recognition) describe and correspond to the play of primary retention (apprehension), secondary retention (reproduction) and protention (recognition). I have tried to show, however, by re-examining the Kantian example of numeration, that the schematism, as projection by the transcendental imagination of pure concepts of understanding in the 'manifold of intuition' (that is, in the retentional flow that constitutes phenomena), presupposes schemas that are themselves constituted through tertiary retention - and on the basis of sensorimotor schemas. ${ }^{1}$

The consequence of this point of view is that so-called 'transcendental' imagination presupposes a primordial exteriorisation of memory and therefore of the imagination itself, that is, of anticipation and temporalisation, such that, passing through artefactual schemas configured by technical organs as tertiary retention, it is supported by a spatialisation.

Tertiary retention in general is the spatialisation of time enabling its repetition and its exteriorisation, and the trans-formation of the time of retentions and protentions into a space of retentions and protentions. In a general way, all technical production of the technical form of life by the desiring and dreaming beings that we are, constitutes such a spatialisation of experience and thereby also enables its intergenerational transmission: such is epiphylogenesis, which constitutes the origin of 
what Canguilhem called the technical form of life insofar as it breaks with the conditions in which life had evolved up to that point: it breaks with evolution as conceived by Darwin. It is this rupture that constitutes archi-cinema, establishing a libidinal economy of movement.

What I call tertiary retention is what Derrida called the supplement insofar as it has a history, that is: as the genesis of technical concretisations of archi-writing (or the archi-trace). I am not in complete agreement with Derridian theory stricto sensu to the extent that this theory does not seem to me to distinguish primary retention, secondary retention and tertiary retention as such. In this, my 'theory of the architrace', so to speak, which is not only archi-writing but archi-cinema, that is, a system of editing and post-production of primary, secondary and tertiary retention and protention (which constitutes differentiated regimes of traces), differs considerably from the exposition in Of Grammatology, above all because I think the supplement essentially in relation to tertiary retention, that is, to technics, whereas for Derrida the archi-trace constitutes the living trace in general - well before the appearance of tertiary retention.

In any case, in this framework, the history of the supplement is that of tertiary retention, and it is necessary to distinguish between epochs, and in particular that of grammatisation as the capacity to project mental temporal contents into spatial forms. It seems that this possibility, which appeared during the Upper Paleolithic, brought about the emergence

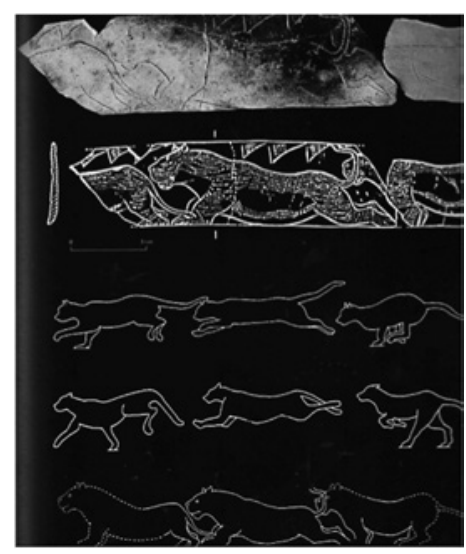

of what the archaeologist Marc Azéma describes in La préhistoire du cinéma ${ }^{2}$ as the origin of cinema, insofar as it was the discretisation and proto-reproduction of movement, 

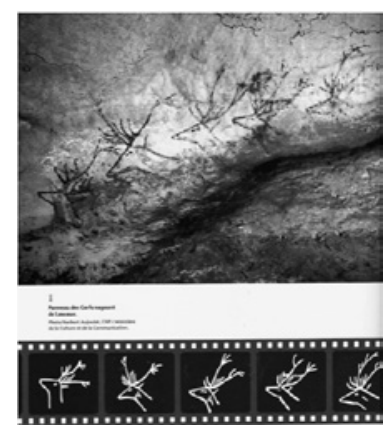

of which that cinema that appeared in industrial form in 1895 would be the mechanical culmination.

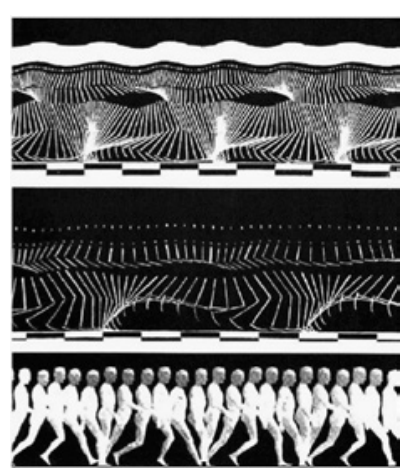

In other words, archi-cinema - which constitutes the omnitemporal conditions in which, in a general way, the technical form of life, which is also the noetic and oneiric form of life, that is, the desiring form of life, rests on processes of the projection through montages of primary, secondary and tertiary retention and protention - was concretised in the form of retentional systems projecting and spatialising movement in prehistoric caves (on the walls of these caves),

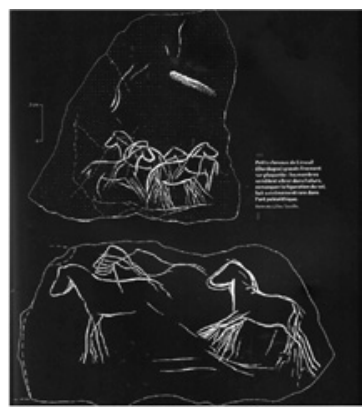


and this led, eventually, to movie theatres and movie screens as we know them today,

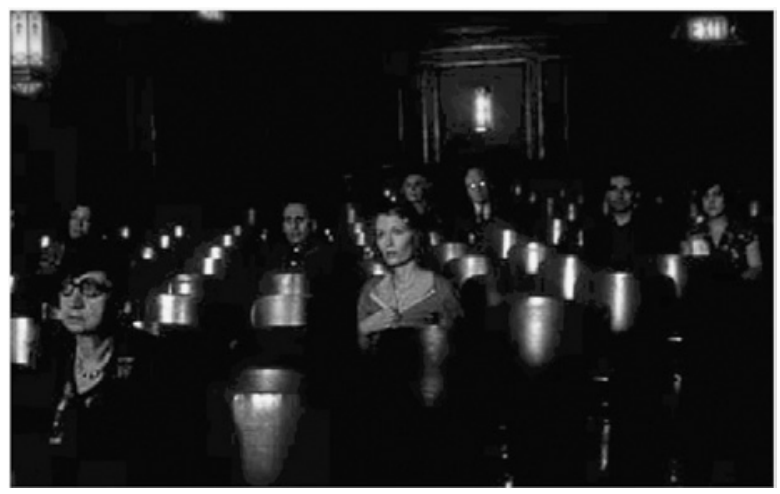

as phenomena typical of the twentieth century (in the sense stated by Godard).

It should be noted here that this cinema of caves and theatres is staged by Plato at the beginning of book VII of the Republic

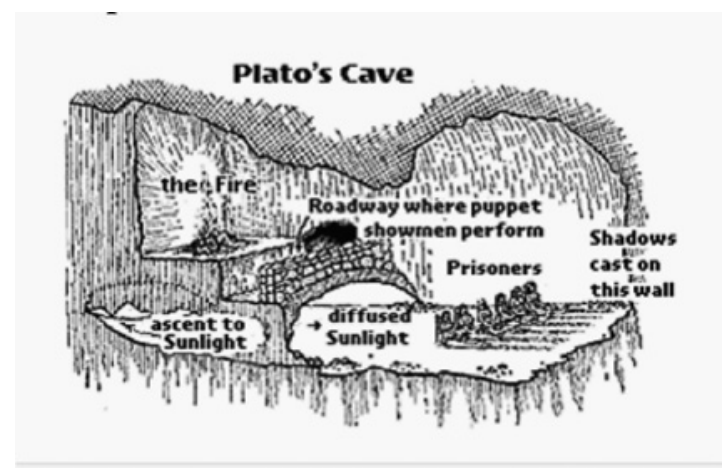

as a kind of dream: as the dream of that dream that would be the lie of life lived in the cave - that is: in the pharmakon. Now, we see that whereas the philosopher wants to leave the cave, the film-lover, the amateur de cinéma, would like to get behind the camera or into the screen: what the film-lover loves is the pharmakon and the pharmacological condition itself insofar as it is also the condition of desire. 


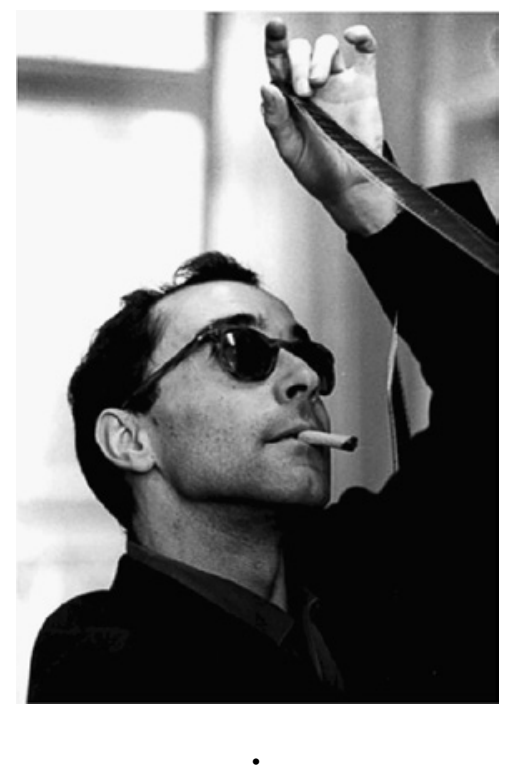

We must, however, here return in a more precise way to the question of knowing in what grammatised tertiary retention consists, so that we may attempt to grasp what is at stake with the advent of digital tertiary retention in the history of cinema.

There are epochs of tertiary retention, and these are the result of the 'organo-genesis' in which consists the transformation of psychic and social organisations that result from the transformation of technical and technological organs. In a general way, the becoming of the pharmakon that is tertiary retention is over-determined by the play of psychosomatic organs, technical organs and social organisations. The relations between these three types of organs are regulated by 'therapeutics' that define social organisations through social systems (in the sense of Niklas Luhmann and Bertrand Gille). Such therapeutics, which aim to strengthen the curative aspect of pharmaka and to limit their toxicity, are libidinal economies, themselves conditioned by the organology of tertiary retention, which means that an organology of the dream in each epoch concretises and specifies the primordial matrix of archi-cinema.

In other words: archi-cinema constitutes the general principles by which primary, secondary and tertiary retention combine, irrespective of the form of tertiary retention; however, the history of the supplement, which implements this archi-cinema, that is, this libidinal organisation of technical life in general, is what concretises itself during the course of 
organo-genesis - and notably as what since 1895 we refer to as 'cinema'. We ourselves, however, find ourselves living in 2014, that is, in the epoch of digital tertiary retention, which makes possible, for example, a cinema without film:

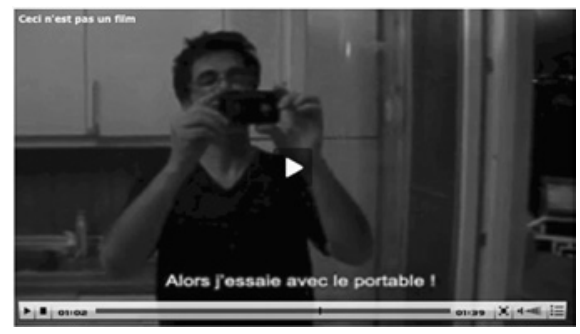

What type of cinema might emerge from this new stage of the history of the supplement as the concretisation of the archi-cinematic power to dream? To try and pose this question correctly, we must return to the history of tertiary retention such as it is inflected through grammatisation.

A text is a fabric of literal tertiary retentions constituting a spatial linguistic object, whereas oral speech is a temporal linguistic object. The textual spatial object is retemporalised by the reader in the course of reading: reading is the trans-formation of space into the time of reading. A film, too, is a spatial object that can only be re-temporalised via the mediation of that piece of apparatus we call the projector, just as playing a record requires a turntable. In general, however, whereas I myself play my records on my own turntable, films are on the contrary screened by a projectionist who operates the projector on behalf of the movie-going public in the movie theatre.

In all of these cases, re-temporalisation constitutes a projection in the course of which readers, listeners and spectators pro-ject their own secondary protentions and retentions into the textual, musical or cinematic flux, and select primary retentions, which then generate primary protentions. As a result, the fact that these selections are each time singular (conditioned by the retentional and protentional characteristics of each of us) means that nobody ever reads the same book, or hears the same music, or sees the same film.

And yet, a book, a piece of music or a film have effects on their public, their audience, that seem to go beyond the various ways of living these effects. This is so because: 
- on the one hand, each type of tertiary retention configures attentional forms that are specific, but common to those who practice this tertiary retention: attention is what results from the play of retention and protention in general (primary and secondary), and the types of tertiary retention, by conditioning this play, constitute attentional forms;

- on the other hand, a writer, a musician or a filmmaker in each case mobilises a common retentional and protentional ground (or fund) constituted by proto-retentions and proto-protentions, typical of a cultural region and an epoch, and which itself takes shape on an archi-retentional and archi-protentional ground, that is, on the basis of archaic elements that derive from what Simondon called the 'preindividual' (under the influence of Jung and his theory of individuation).

In the course of a projection, whether of a book, a record or a film, the play of primary, secondary and tertiary retention enables the projection of repressed elements, individually as well as collectively. This is why I say in An Organisation of Dreams - Ken McMullen's movie - that a film is always the arrangement of an individual history and a collective history. Conversely, and through introjection, the viewer of a film interprets his own retentional and protentional funds on the basis of the transindividual material that is presented during the screening and that comes to meet the audience like an event.

Cinema, however, is a pharmakon, as Frank Capra showed.

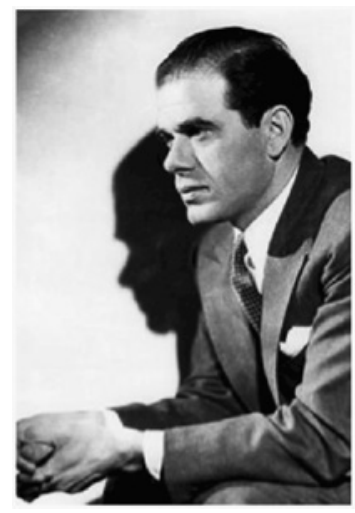

Le cinéma est une maladie. Lorsqu'il atteint votre sang, il devient vite l'hormone numéro un; il supplante les enzymes, commande la glande pinéale, joue avec votre psyché. Comme avec l'héroine, le seul antidote au cinéma est le cinéma.

And this means that the cinematic experience can either reinforce stereotypes held by the public, or on the contrary put to work its traumatypes. 
In order to examine these questions, which will lead to the question of the cinematic condition in the epoch of digital tertiary retention, it is necessary that we more closely analyse the organology and pharmacology of the cinema as an industry of analogue tertiary retention at the service of the consumerist libidinal economy, that is: destructive of this economy, destructive of the libido insofar as it is an economy of the drives, and finally, destructive of attention insofar as, as the arrangement of psychic retention and protention forming motives (objects of desire) from the fabric of collective retentions and protentions, it takes care of its objects insofar as they are objects of desire.

Cinema is seen by Adorno and Horkheimer as a functional element of a system the aim of which is to disseminate an ideology and stimulate consumer behaviour. This view of cinema is not fundamentally different from that of the New Wave, except that the latter saw cinema as a pharmakon, and not just as a poison (this pharmacology, for example, forms the background of Godard's Contempt).

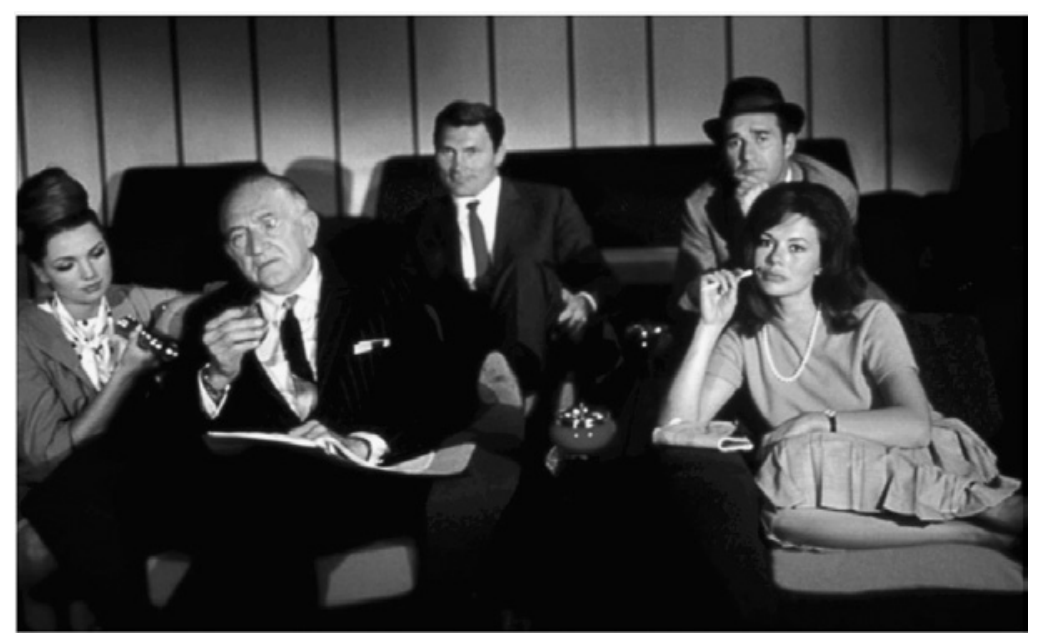

The cinematic art, according to Capra, struggles against the disease that is cinema with the means of cinema. ${ }^{3}$ 


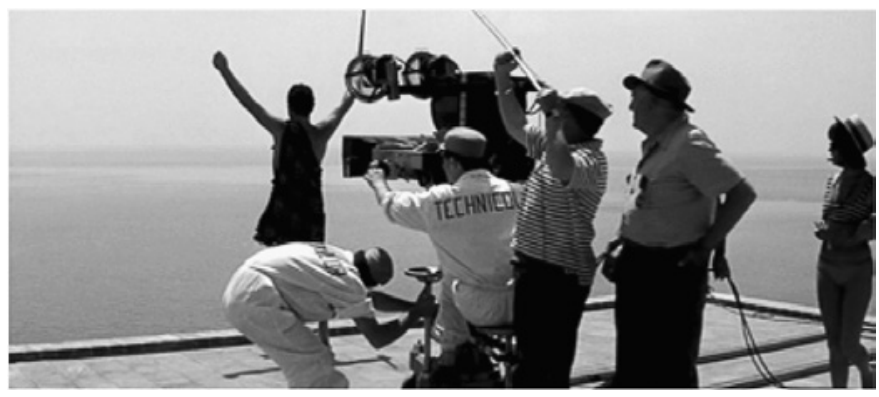

This pharmacology, I suggest, is that of desire, that is, of the dream. What is a dream? It is a compromise between traumatypes buried and repressed in the unconscious, and the stereotypes in which they are clothed in order that they may manifest themselves as 'latent content' - the manifestation of this content remains latent so that it may be translated in waking life into action, and interpreted through our actions, which may include speaking, as in the psychoanalytic cure.

In other words, we must think of this as a loop (that is, a circuit) the moments of which must not be separated - and this is what Simondon taught us in Invention et imagination: for Simondon, in the imagination, every image founded on sensorimotor schemas and passing through what he calls the image-object, results in an invention, that is, an individuation - and a film is such an individuating invention.

A film is a kind of dream had in common, a daytime dream, via the means of the industrial production of tertiary retentions that are themselves industrial. Insofar as it is a dream, film manifests a desire - a desire that we imagine to be that of a public, that is, of an epoch, and not just that of a filmmaker. This is why Godard, under the (false) belief that he was citing Bazin, ${ }^{4}$ could say that:

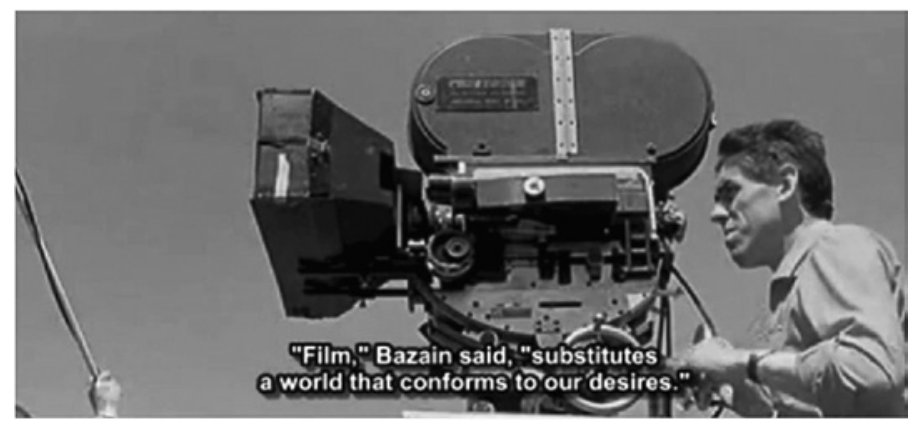

film substitutes a word that conforms to our desires. 
In reality, it is a matter of the desire of the filmmaker in that - like the desire of any artist - he or she succeeds in sharing it through their work; and here let's see how Godard reread and reinterpret his own quotation of Bazin in Contempt almost thirty years later:
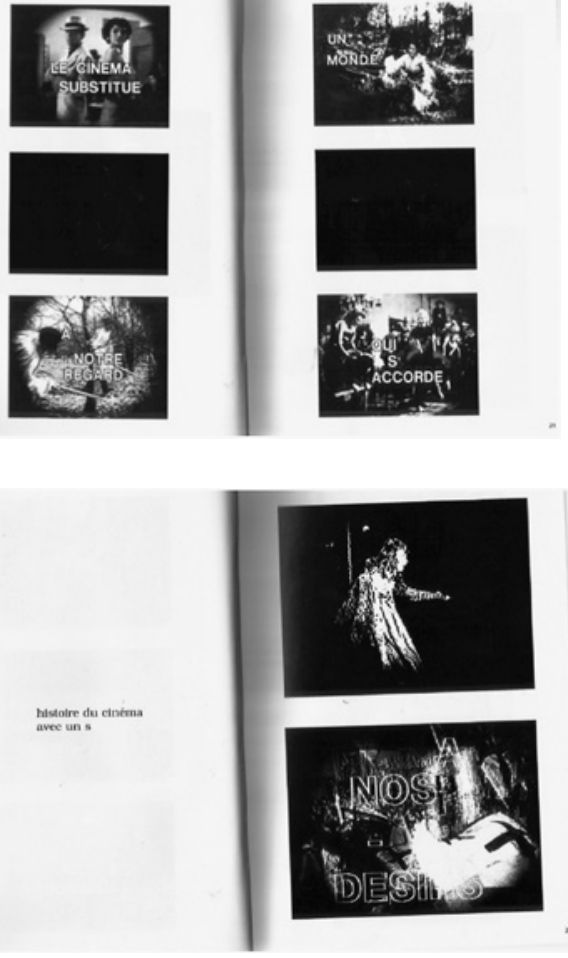

ea
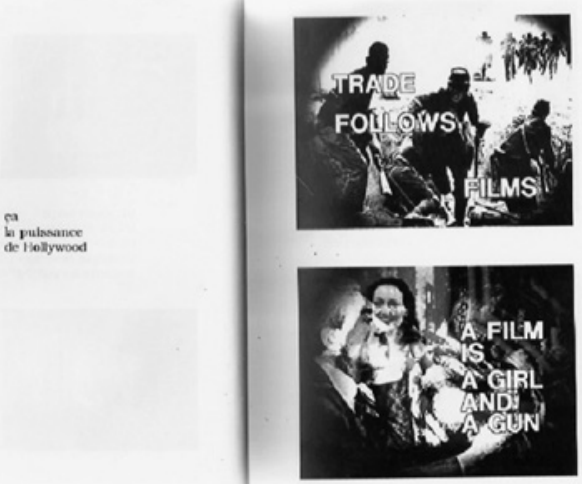

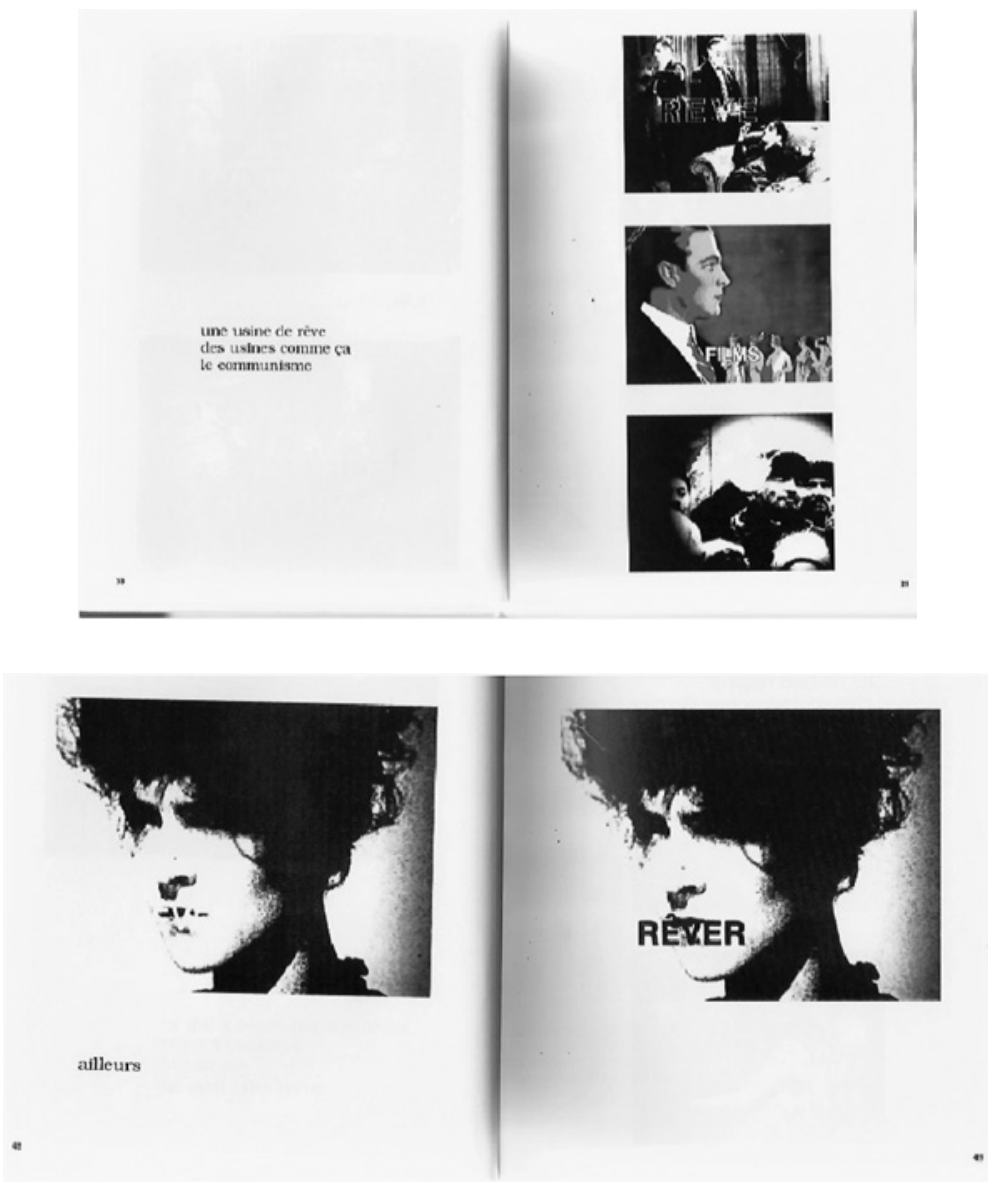

And in making it, by sharing this desire through his or her work, the filmmaker makes a vehicle of the transindividuation of his or her epoch. Furthermore, this transindividuation works by socialising and transindividuating the tertiary retentions of the epoch in terms of reinforcing psychic individuation as well as collective individuation, rather than in the sense of disindividuation, that is, reinforcing stereotypes.

What Adorno and Horkheimer argue is that cinema is more than anything else this process of disindividuation. And one could say that this is the drama of cinema, and that it is the drama represented by every great director. This is also and especially the case for Fellini who, in Intervista, inscribed this pharmacology of cinema within the perspective of its becoming television. Fellini is a particularly interesting director in terms of an examination of the relation between cinema and dream - and Intervista is indeed a dream, 


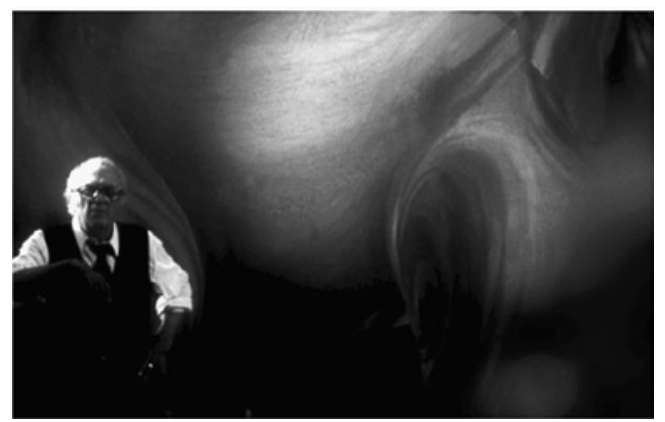

as depicted in the first scene of the film. But this dream is also a kind of nightmare - that which Berlusconi will bring to Italy and to Italian cinema, but also that of the Mussolinian origin of Italian cinema, which is a recurring theme in Fellini, as can also be seen in Amarcord:

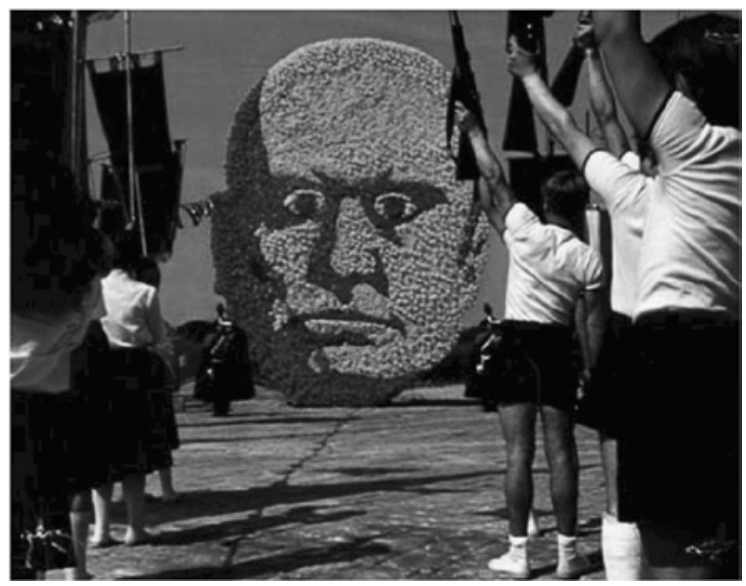

Beginning in 1960, when he first started to see the Jungian analyst Ernst Bernhard, Fellini would sketch his dreams each morning.

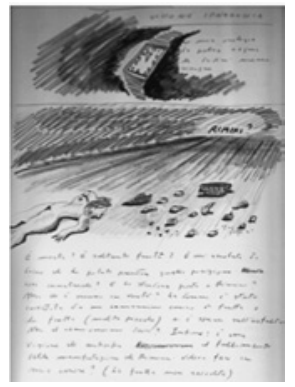


These dreams were transcribed in notebooks, and later published in France by Flammarion.



We are still only in the prehistory of the animated image. And the true history of television begins, perhaps, with Skype. Television is certainly not cinema. But what is cinema? Is it, for example, tied to actual celluloid film?

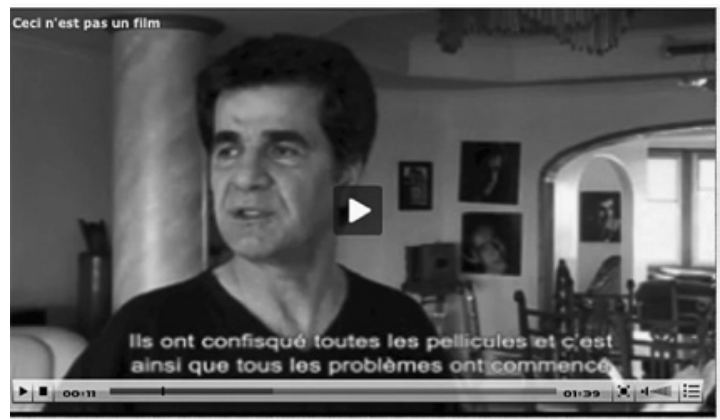

Films are analogue forms of tertiary retention. So are videotapes. But what happens to archi-cinema in the age of digital tertiary retention?

The retentional change brought about by digital tertiary retentions radically changes the relation to the moving image and sound, both because it turns this into an everyday practice engaged in by everyone, for example through Skype, webcams and smartphones, and because it makes possible, for example, that of which Godard dreamt during a visit to Canada in 1978:

like a novelist $[. .$.$] needs to have a library in order to know what is being done, to$ receive books by others [...], so as not to have to read only his own books; and at the same time, a library that would also be a printing press, a print workshop, to know what it is to print; so too for me, a film studio is something that is at the same time like a novelist's library and a print workshop. ${ }^{5}$ 
We are in this way living through a transformation comparable to that which resulted from the passage from hieroglyphic writing to alphabetic writing. What does all this do to our dreams? This question is at the same time psychological, political, economic and industrial. And in this context, Youtube now creates open studios everywhere in the world

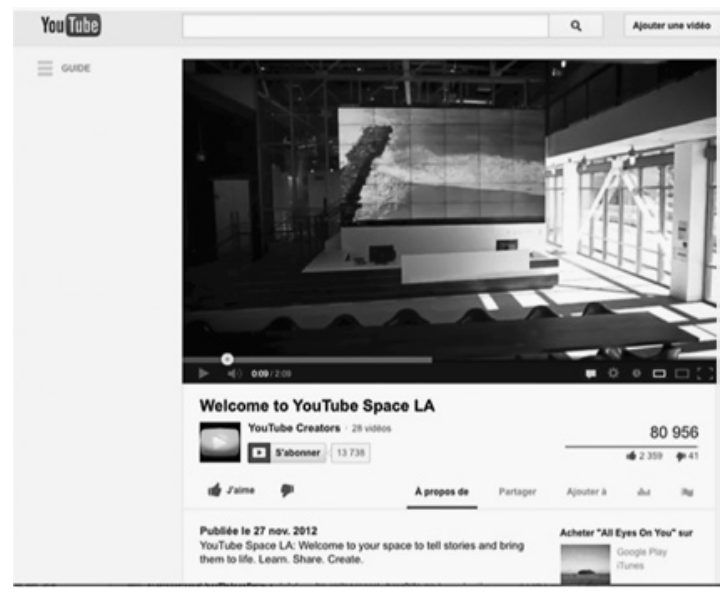

where you can learn, share and create

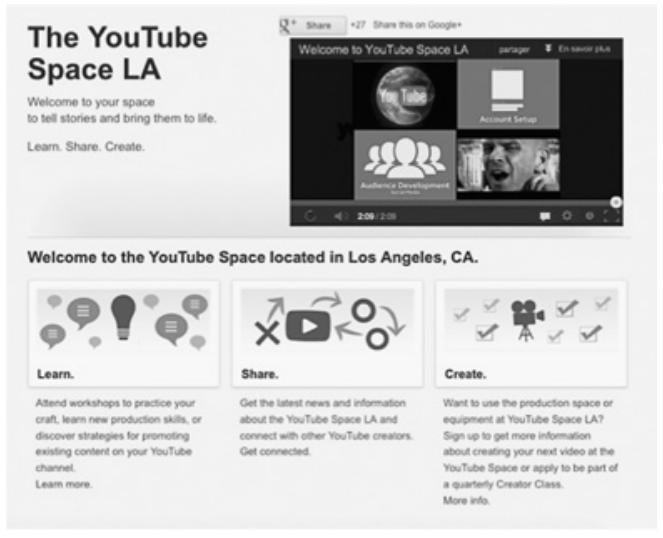

A dream is a moment within a noetic sensorimotor loop, and it internalises an artefactual (that is, heteronomic) retentional organisation, into which the dream tries to introduce a coherence - a coherence with desires that are, however, in conflict with the social organisation that is concretised around this organology, and which incarnates a superegoic structure.

Such a structure produces much stupidity: through the use of collective retentions in order to keep a rein over individual and collective 
traumatypes, it generates stereotypes. By constantly reinforcing these stereotypes, and by taking them to the extreme, the consumerist capitalist economy that is initially cinematic and then becomes televisual, in the end destroys the libido, which decomposes into the drives, killing the power of cinema to dream: aside from some very remarkable exceptions, cinematic dreams become drive-based nightmares, that is, horror movies.

The film industry has been the capitalist stage of the libidinal economy and of the organology of dreams - which are the workshops or studios of this libidinal economy. It was in this capitalist and industrial context, in which cinema is put at the service of consumption and leads eventually to television that Capra understood cinema above all as a form of dependence that 'takes over as the number one hormone [...], bosses the enzymes [and] directs the pineal gland'. This pharmakon is dangerous because it may take the place of something that you, your body and your brain knows how to do itself, which is also to say, to produce - 'as with heroin', as Capra puts it, that is, in this case, in relation to endorphins.

Since the pharmakon is better at producing it than you are, you 'unlearn' how to produce it yourself. This is what happens to the heroin addict. It is also what happens with writing, if we are to believe Socrates. And it is what means that industrial organology takes the form of proletarianisation, which Marx described in the first place as a loss of knowledge. In the case of the cinematic pharmakon that becomes the televisual pharmakon, which proletarises consumers and deprives them of the capacity to produce their own savoir-vivre, the capacity to know how to live, it is the primary and secondary identification processes, which constitute the condition of formation of the psychic apparatus, and therefore the condition of production of libidinal energy, that are effectively shortcircuited.

That cinema is an industry means that its model and its means of production rest on an opposition between 'production' and 'consumption': this opposition, according to Adorno and Horkheimer, expresses itself as a teratological exteriorisation of the transcendental imagination. But what they fail to see is that the problem is not exteriorisation, which has always already begun, but rather the short-circuit that inevitably results from the hegemony of de-symbolising, disindividuating and imagination-destroying cultural consumerism, because it reinforces stereotypes and represses traumatypes. 
Digital tertiary retention establishes a new industrial organology that poses all these problems in new terms that make possible new dreams - and, on this precise point, we must also relate this to the projections made possible by the Super 8 camera (as Alain Resnais, for example, shows in Muriel) and the 16 millimetre camera in the 1950 os in France.

With regard to what was said by Jean-Luc Godard in his Histoire(s) $d u$ cinéma, a project anticipated in his Introduction à une véritable histoire du cinéma, in which he dreamt of a film library

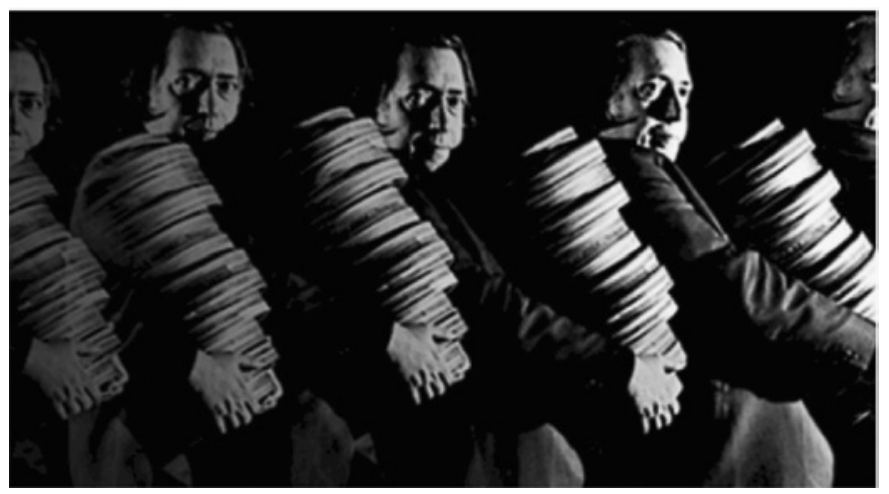

as has today become available online - well not quite yet, but it will be soon and in the true sense, for soon we will be able to browse films, and access them in conditions made possible by their digital grammatisation, as foreshadowed by Lignes de temps:

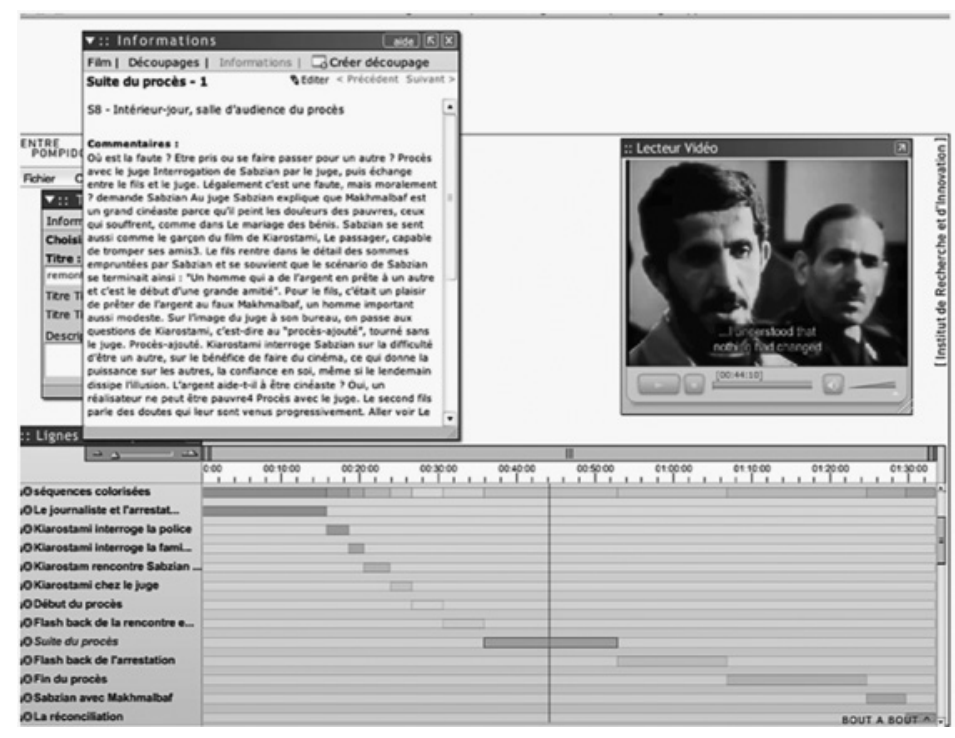


- in regard to this dream of Godard, we must understand that his films were immediately and completely underpinned by this dream and its organology. And this suggests that we have much to expect from digital organology, insofar as we know how to desire, to dream, and to concretise this positive pharmacology.

In the late 1950s, when Godard and the critics of Cahiers du cinéma were dreaming, when cinema was the dream, and because their dreams were organologically constituted by the cinema, these lovers of cinema Godard, Truffaut, Resnais and so on - became the New Wave of cinema through their political and economic thought of an emerging organology, just as Fellini had such a thought in relation to cinema in general: the cinema of Fellini like the appearance of the New Wave derived not from an organological causality but from an organological conditionality, that is, a pharmacological conditionality, so that, for example, in the context of Berlusconian television, Fellini rethought, in the course of a dream, the Mussolinian pharmacology of delusion that gave birth to Italian cinema.

In the age of Cahiers du cinéma, the appropriation of the 16 millimetre camera radically changed the relations of production at the core of the cinematic machine, and thus changed the cinematic imagination of filmmakers and their audiences, which became, in a structural way, amateurs, film-lovers: one of the very specific features of the New Wave was that its public was composed of film-lovers. Now, these filmmakers were themselves lovers of cinema who took hold of the 16 millimetre camera in order to show what they had seen in 35 millimetre cinema. One cannot see the films of the New Wave without being a lover of cinema, just as the directors of the New Wave were themselves film-lovers.

At the beginning of Intervista Fellini is in the middle of a dream. This film shows a dream that builds on notes made by Fellini in his sketchbook. Here, the question of note-taking is that of the organological conditions of the dream as it is elaborated through the taking of notes. What is a dream, if not a kind of montage of these notes that are 'day residue', to speak in psychoanalytic terms? Intervista, however, is a waking dream, a kind of daydream. But what is a work, an oeuvre, in general, if not such a dream made out of artefacts, that is, made from transitional objects of all kinds?

During a dream, I transindividuate within myself in a way that runs counter to the dominant transindividuation - the dream puts into movement traumatypes that are hidden behind stereotypes, which is also exactly what happens in any good movie - yet my power to dream is the 
condition of my power to act, the one like the other being conditioned by the same organological powers and impotencies. By articulating and arranging organs, the brain with the bladder, for example, as a source of internal sensations, or with the ear, as a source of external sensations (these are examples given by Freud in The Interpretation of Dreams), via a given symbol, which is always one of tertiary retention, that is, an artificial organ, organology mobilises phenomena occurring during the day (daily residue) that it brings up - as Fellini did with his memories of the years from Mussolini (at the beginning of Italian cinema) to Berlusconi (in the age of Berlusconi's television).

Nocturnal organology is not the organology of daytime. This passage from night to day, of which the industrial dream projected in the movie theatre blurs the difference through 'day for night' techniques (which in French are called 'la nuit américaine'), may result in traumatypical liberation but in the guise of stereotypes, turning cinema into a political power to harm stupidity by working with it - through these stereotypes that are the pharmacological condition of traumatypes, and in this regard especially, Intervista is exemplary.

We are projectors (as Godard said) capable of projecting traumatypes, of socialising, of transindividuating on the basis of our means of production, that is, on the basis of the organological powers and knowledge of which we are capable - that we are capable of putting to work. And this capacity forms the stakes of a political struggle, and especially in the context emerging from cinema in the epoch of digital retention. The economy of the 'means' of oneiric production raises the question of the ownership of the means of production of the dream, the imaginary and the symbolic.

In Close-Up, Kiarostami tells the story of Hossein Sabzian,

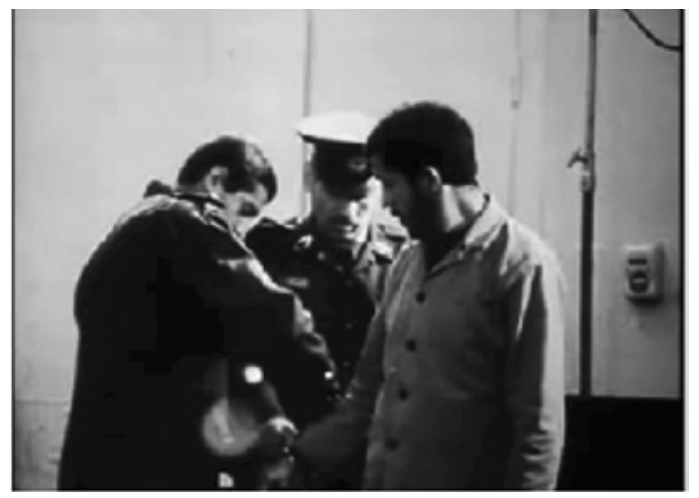


who finds himself in prison because 'il se faisait du cinéma', as one says in French, meaning that he gets caught up in his own lies - and in his lies, in his movie, he dreams of making a movie. In other words, there are, for Sabzian, two dimensions to his cinema: the movie that he lies about [le cinéma qu'il se faisait], and the movie that he cannot make, the film that he does not get a chance to realise, to direct.

Kiarostami has made a film, and in a way he has realised the dream of Sabzian - which was to make a film. Kiarostami interprets Sabzian's action by suggesting that Sabzian dreamed of passing into the screen. I believe, rather, that his dream was to get behind the camera. Sabzian's dream was to make films: it was the dream of Godard, of Resnais, of Truffaut.

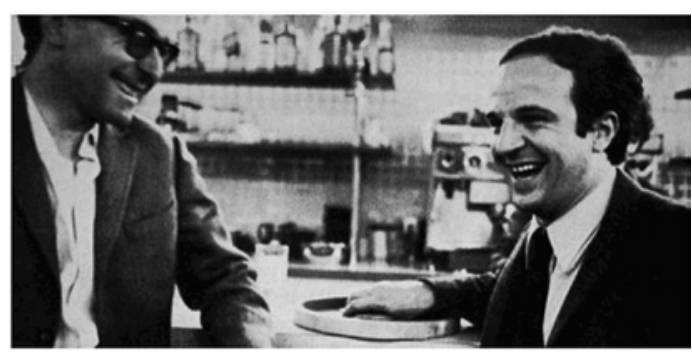

Close-Up shows that this dream is shared a little by all the Iranians we see in the film, and not just Sabzian. Furthermore, Makhmalbaf has Iranians speaking about their dreams of making films in his own film, Salaam Cinema,

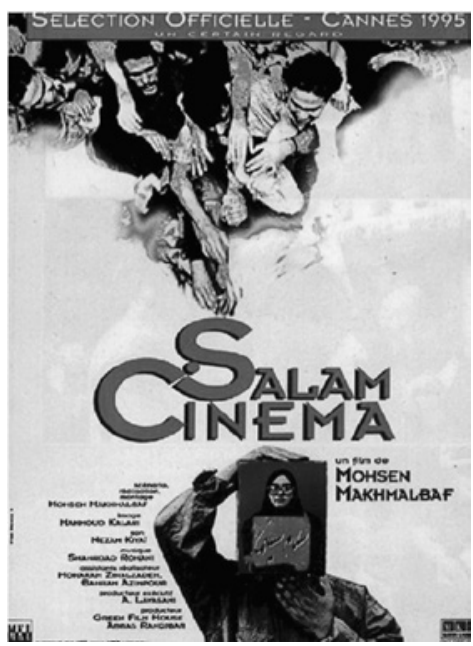

a film that was shot in the wake of Close-Up. 
In Close-Up, everyone is more or less a film-lover. And as for Sabzian, a poor, unemployed resident of Tehran, he manages to find the means, even though he barely has enough to eat, to buy a copy of the screenplay of The Cyclist,

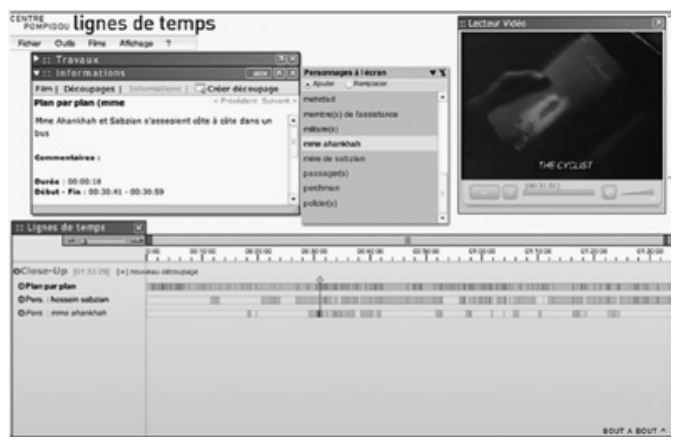

a Makhmalbaf film that he greatly loves: he was so in love with it that he wanted to study it further - and we see in his trial (filmed by Kiarostami) that he had been writing screenplays for a very long time, and that he accuses his father of having taken him to the cinema, that is, of having initiated him into and encouraged a passion that would eventually lead him to prison.

An ancient thesis states that, in fact, the origin of technics is the dream, and that as such, technics can never be defined as the causal factor, this being the dreamed idea - one could say the fantasy, or the protention. This is, in a way, the argument of both Bazin and Georges Sadoul.

- Ce que révèle paradoxalement la lecture de l'admirable livre de Gcorges Sadoul sur les origines du cinéma ( $L$ 'Invention du cinéma ${ }^{2}$ ) cest, en dépit du point de vue marxiste de l'auteur, le sentiment dune inversion des rapports entre l'évolution économique et techaique et l'imagination des chercheurs. Tout me semble se passer comme si l'on devait renverser ici la causalité historique qư va de Tinfrastructure économique aux superstructures idćologiques et whsidérer les découvertes techniques fondamentales comme des ccidents heureux et favorables, mais essentiellement seconds par rapport à lidée préalable des inventeurs. Te cinéma est un phéno- Éne idéaliste. L'idée que les hommes-s'en-sent-fait extistait tout armbe dans leur cerveau, comme au ciel platonicien, et ce qui nous. frappe cest bien plutôt la résistance tenace de la matière à l'idée, que las suggestions de ta technique dy t'magination du chercheur. Aussi bien le cinéma ne doit-il presque rien à l'esprit scientifique. Ses pères ne sont point des savants (Marey excepté, mais il est significarif que Marey ne s'intéressait qu'à l'analyse du mouvement, nullement au processus inverse qui permettait de le recomposer). Même Edison n'est au fond qu'un bricoleur de génie, un géant du concours Lépine. Niépce, Muybridge, Leroy, Demenÿ, Louis Lumière lui- 


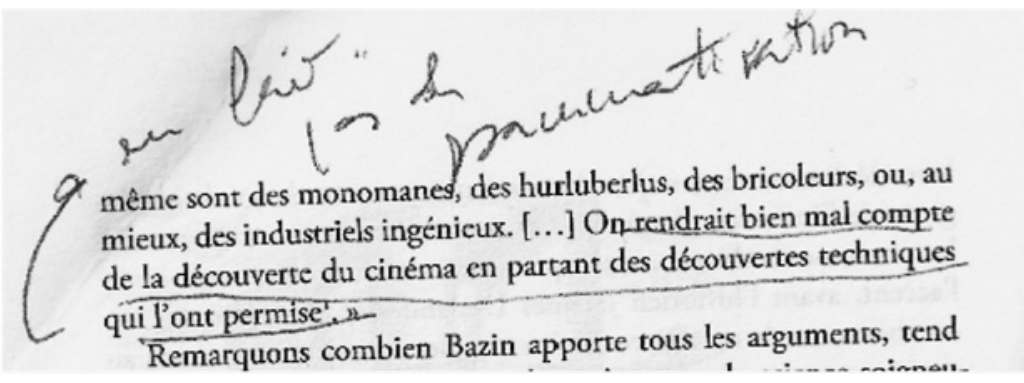

A large manufacturer of film and audiovisual equipment, Sony, based its advertising on just such a representation of the genesis of technics. In reality, dreams generate technics, which itself generates dreams: dream and technics cannot be separated. In his Préhistoire du cinéma, Marc Azéma begins by speaking about dreams: he says that while animals dream, only human beings externalise their dreams.

I think he is right that this is how tertiary retention forms. This exteriorisation of dreams, as the capacity to produce what Simondon, at the beginning of Imagination et invention, called, precisely, invention, and that he defined as the fourth moment of what he referred to as the cycle of images, presupposes tertiary retention as the process of grammatisation of archicinema, that is, as the concretisation of this archi-cinema, but which would also be its transformation.

The transformation of desire by this archi-cinema is what makes possible technical and technological projection and invention, on the basis of earlier technics and technologies - tertiary forms of retention generate, under certain conditions, other forms of tertiary retentions, when what we refer to as the technical system of the imagination or the ideas has reached its limits. We ourselves, today, are at the limits of the imagination and ideas generated by analogue tertiary retentions, and we are entering into a new system, the digital system.

I do not mean that the invention of the digital occurred because the analogue system had reached its limits: I mean that the oneiric being that we are, a being that is also noetic, is essentially constituted by the co-evolution of its dreams and its technics. Sabzian's dream was in fact of something that could actually take place, something that the Medvedkine groups 


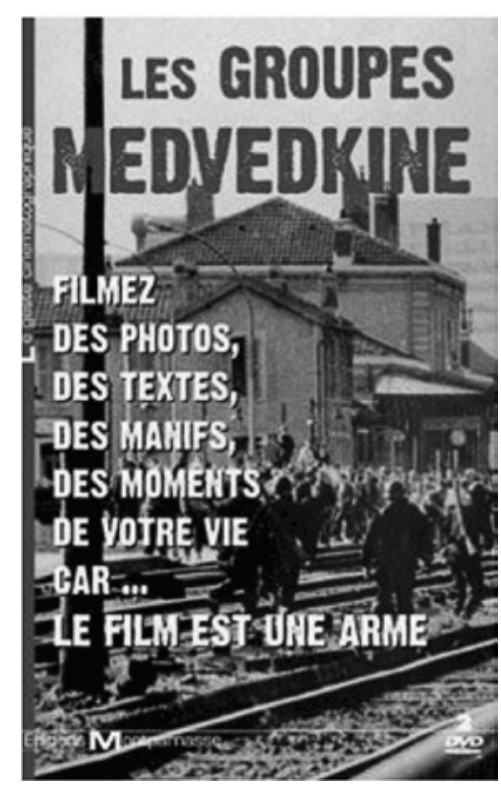

realised with Chris Marker, inspired by Medvedkine himself, something that the militant workers of Besançon actually managed to bring about. These were not exactly French Sabzians, but they resembled him a little, going on strike in the extreme conditions of 1967 while at the same time wanting to incorporate into the factory a library and a cinema, as Paul Cèbe actually did, and did so at the initiative of these groups, ${ }^{6}$ producing something that is of the order of an organological dream.

Godard, in 1978, eleven years after the Medvedkine groups, thinks cinema in terms of the relation between impression and expression:

Cinema $[. .$.$] enables you to impress an expression and at the same time to ex-$ press an impression; there are both. ${ }^{7}$

This can be linked to what Simondon said about the cycle of images. ${ }^{8}$ Godard, too, speaks of a cycle of images - he thinks cinema, however, in relation to desire, of which he investigates the pharmacological and organological conditions through cinematic invention.

In the book from which these quotations are taken and of which the exact title is Introduction à une véritable histoire du cinéma et de la télévision, that is, Introduction to a True History of Cinema and Television, one of the first images that Godard uses and that he projected during those conferences that screened some of his films, set against films taken from 
the history of cinema, dramatises the question of the relation between film and video:

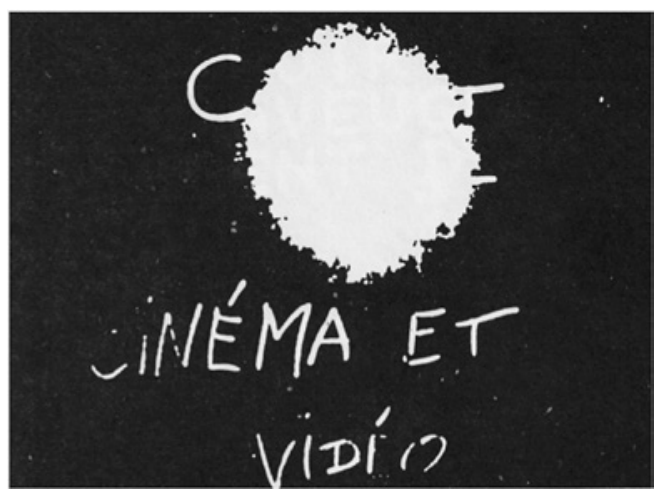

If Godard emerged from the $16 \mathrm{~mm}$ and Super 8 revolution, which played such an important role for Resnais, if Godard continues to write in ways that articulate different types of analogue tertiary retention, assembling them with one another, for example by making notebooks and collating drafts and notes such as I spoke about in relation to dreams, by 1978 , twenty years after the appearance of the Beaulieu camera and the birth of the New Wave, he is investigating video:

People should write scripts on video, because seeing a shot would help you decide how or how not to shoot it.

Godard emphasizes that television could be used to see, and that at the moment it is used to prevent seeing, or in other words, that it is a pharmakon:

Since everyone has a TV [...] they have to make people forget that it can be used to see.

He is thus already raising the question of moving from analogue film, based on silver halides, to electronic film - while stressing the pharmacological dimension of cinema in terms reminiscent of Capra:

Cinema [...] impresses in advance the great movements that are going to take place. It is in this sense that it can show diseases before they happen.

The digital could and should eventually fulfil the expectations of Godard's dream of a library of cinema that would also serve as a print workshop, as well as Sabzian's dream of offering everyone the possibility of making films - provided a politics of the organological condition and 
the pharmacological situation of human dreams is placed at the heart of political economy. This means that the political world must make this its motive. But this will not be possible if the film world (amateurs and 'professionals') does not mobilise itself in this direction.

Marx argued in The German Ideology that idealism is based on an inversion of cause and effect that forgets the role of the means and relations of production in the genesis of ideas, and he compares this illusion to the reversal of the image in the retina. For Plato himself the cave was a place of illusion - and he founded idealism by suggesting that it is necessary to get out of the cave in order to re-locate what Adorno himself called the light of day, that it is necessary to leave the movie theatre.

What Sabzian wants, and Godard, Resnais and Kiarostami want, what all amateurs du cinéma want, all film-lovers embodying this archi-cinema that Plato described but without having any way of seeing the scope of what he was describing, was not to leave the projection room: it was to get behind the camera - as shown recently by Michael Gondry in Be Kind Rewind. Such are the stakes of the digital, and this constitutes a new page, still completely blank, of the history of archi-cinema.

Translated by Daniel Ross

\section{Notes}

1. On this subject, see Gilbert Simondon, Imagination et invention (Chatou: Éditions de La Transparence, 2008).

2. Marc Azéma, La préhistoire du cinéma: origines paléolithiques de la narration graphique et du cinématographe (Paris: Errance, 2006). And see also Azéma and Florent Rivére, 'Animation in Palaeolithic art: a Pre-echo of Cinema', Antiquity, no. 86 (2012), pp. 316-24.

3. Frank Capra: 'Film is a disease. When it infects your bloodstream, it takes over as the number one hormone; it bosses the enzymes; directs the pineal gland; plays Iago to your psyche. As with heroin, the antidote to film is more film.'

4. From the French Wikipedia entry on Godard's Contempt: 'In the final epigraph to the film, Jean-Luc Godard attributes to André Bazin the following quote: "Cinema replaces our gaze with a world that conforms to our desires." This quotation actually derives from an article by Michel Mourlet, entitled "On an ignored art", which appeared in Cahiers du cinéma in 1959. The precise quote is: "Cinema is a gaze that replaces our own with that of a world that conforms to our desires".'

5. Jean-Luc Godard, Introduction to a True History of Cinema and Television (Montreal: Caboose, forthcoming). 
6. 'It could be said that everything begins with a library, with the political will for a library at the heart of the factory. When the worker Paul Cèbe managed to extract the opening of a library in the middle of the Rhodia plant at Besançon, he opened a breach. Through it he brought books, culture and other forms of consciousness into the daily struggle that is the factory. Paul Cèbe also loved films. He organised, thanks to a Parisian friend, screenings of films and presentations by the directors themselves. The friend was named Chris Marker. The directors who were invited were Agnès Varda and Jean-Luc Godard, among others.' Sébastien Rongier, at: remue.net.

7. Jean-Luc Godard, Introduction to a True History of Cinema and Television.

8. And it is necessary to mention here, for example, what Godard said about money and the image or the likeness of Louis XVI, about the representation of the king on coins and its role in the process of transindividuation under the control of monarchical authority. 